\title{
The Unfinished Referendum Process in Western Sahara
}

\author{
By \\ Terhi Lehtinen
}

Terhi Lehtinen is the Programme Officer at the European Centre for Development Policy Management (ECDPM), Onze Lieve Vrouweplein 21, 6211 HE Maastricht, The Netherlands;

Tel: +31 43350 2923; Fax: +31 43350 2902; E-mail thl@ecdpm.org

\begin{abstract}
The Western Saharan conflict, between Morocco and the Popular Front for the Liberation of Saguia el Hamra and Rio de Oro (Polisario), has constituted a major threat to regional stability in North Africa since the Spanish decolonisation in 1975. The war has cost thousands of lives, with prisoners of war taken on both sides, and forced Morocco to construct a huge fortified wall in the Sahara. The conflicting parties have a fundamental disagreement on the status of Sahara; Morocco claims its marocanity based on the region's historical ties with Moroccan dynasties. In contrast, the Polisario fights for the Sahrawi people's right to self-determination, bolstered by Organization of African Unity (OAU) principles and United Nations (UN) resolutions. However, the underlying dispute concerns the control of the region's rich phosphate and fish resources. The UN Mission for the Referendum in Western Sahara (Minurso) has played the major role in the organisation of the referendum for self-determination, delayed several times due to disagreement on the voter identification and registration. In January 2001, the Polisario declared the end of the ceasefire, effective since 1991, due to Morocco's failure to respect the agreed principles. The political settlement of the dispute remains difficult to achieve and frustration on the ground is increasing. However, the example of a successful referendum in East Timor gives hope for the future in Western Sahara.
\end{abstract}

\section{Introduction}

The dispute between Morocco and Polisario in Western Sahara is one of the last pieces of the unfinished decolonisation in Africa. The dispute has challenged the most fundamental concepts of international law, such as the OAU principles of inviolability of existing African borders, a people's right to self-determination and its right to sovereignty and territorial integrity. The question of Western Sahara has become the key element for both Moroccan and Sahrawi nationalism and served to strengthen the legitimacy of political regimes in the region. Furthermore, the international involvement in Western Sahara is closely linked to geopolitical and strategic interests of neighbouring countries and the international community in Africa. Finally, the question of a referendum for self-determination as a means to resolve a bilateral dispute offers an interesting case for a political and electoral analysis.

The literature on Western Sahara has become abundant since the $1970 \mathrm{~s}^{1}$. The dispute is often analysed in the perspective of international law ${ }^{2}$, although some geopolitical and 
political analysis is also available. Most authors seem to be openly biased in their analysis, defending either the marocanity of Sahara ${ }^{3}$ or the right to self-determination of the Sahrawi. In this article, I propose to analyse the geopolitical claims and political models presented by the conflicting parties, by the neighbouring countries and the international community, as well as the strategies used to legitimate these claims. In particular, I focus on the modalities of the referendum process. The analysis will distinguish three levels; first, the bilateral dispute between Morocco and the Polisario, articulating the concepts of territorial integrity, right to self-determination and the question of a referendum as a means to resolve the dispute. Second, the role of the neighbouring countries, Algeria, Libya and Mauritania, and the question of regional stability in North Africa, is examined. Third, I look at the role of the international community in Western Sahara, notably the UN, the OAU, the US, France and Spain. I will also explore the impact of the Islamic and Arab nationalist ideologies on the dispute, and reflect on the role of women in the Western Saharan politics. Finally, I will make some concluding remarks on the Western Saharan question.

\section{Historical Background of the Western Saharan Question}

The political structure in Western Sahara dates back to historical relations between different Saharan tribes. Before Spanish colonisation, there was no supra-tribal authority connecting the vast tribal network of the region. However, certain Saharan tribes recognised the religious authority of Moroccan dynasties, descendants of the prophet, based on personal loyalty (bei'a) to the sultan. Despite the sultan's religious authority, most Saharan tribes have constantly contested political authority of Moroccan dynasties in Western Sahara. The Sahrawi constitute a sprawling nomadic collection of tribes, formed from a mixture of Arabic, Berber and black African cultures. Most tribes belong to the Reguibat confederation and speak a specific Arabic dialect, called Hassaniya. Western Sahara was neglected by colonial powers and Spain only maintained superficial authority in the territory since 1884 .

At the end of the 1960s, the discovery of phosphate deposits in the Bou Craa region changed the situation and led to a greater international interest in Western Sahara. In the 1960s, the Sahrawi population experienced a progressive sedentarisation. Morocco claimed its rights on the territory since its independence in 1956. In 1969, Algeria recognised Moroccan claims in a meeting at Ifrane, Morocco. In exchange, Morocco recognised Algerian control over iron mines in Garaa Djebilet (near Tindouf) and agreed on the borders between Morocco and Algeria. ${ }^{4}$ Furthermore, there was a common agreement to build a railway line in the Dra valley between Tindouf and the Atlantic coast. The Ifrane agreement could have formed a basis for a North African economic community. ${ }^{5}$ However, the Moroccan political opposition objected to the abandoning of the Tindouf region to Algeria. As a result, the agreement was never implemented. Consequently, Algeria decided to support the claim for self-determination of the Sahrawi, and later became the main supporter of the Polisario, ${ }^{6}$ established in 1973. In 1974, the Spanish conducted a census of the Western Saharan population with a view to holding a referendum on self-determination.

5 In 1989 the North African states created the 'Union of Arabic Maghreb' (UMA), in order to achieve a regional economic integration. However, since 1994 the UMA has been paralysed due to disagreement among the participating states.

Lacoste, pp77-90 
In 1975, Spain evacuated the territory and the International Court of Justice (IC)) issued a verdict stating that neither Morocco nor Mauritania should have sovereignty over Western Sahara, nothwithstanding their historical claims. Despite the verdict of the international legal body, Moroccan King Hassan II organised the 'Green March' of some 350000 people to advance the Moroccan army into Western Sahara. In 1976, Mauritania, Morocco and Spain signed the 'Madrid Accords', dividing the Western Saharan territory into two, with the northern two thirds going to Morocco and the southern one third to Mauritania. The violent resistance against Moroccan and Mauritanian occupations soon demonstrated the mobilising force of the Sahrawi identity. The Sahrawi Arab Democratic Republic (SADR) and a government in exile were formed in 1976.

In 1979, Mauritania abandoned its territorial claims in the south and recognised the rights of the Sahrawi people by signing a peace agreement. In 1984, Morocco withdrew from the OAU, after the SADR had been accepted as its full member. In 1990, the UN presented a settlement plan and set up Minurso, which was mandated to organise a referendum on the independence of Western Sahara and to compile a list of eligible voters. In 1991, Morocco and Polisario agreed on a ceasefire, which has, to date, remained effective. Meanwhile, Morocco has intensified its policy of the settlement of thousands of civilians in Western Sahara. The referendum process has been constantly delayed, mainly due to a disagreement on voter identification and registration. In 1993-1994, parties finally agreed on voter eligibility for applicants from tribes registered in the 1974 census, and the identification and registration operations could finally start. In 1997, UN secretary-general, Kofi Annan, appointed James Baker as his special envoy to Western Sahara. The 'Houston Accords', concluded in 1997, marked a new step in direct talks between the conflicting parties. Morocco and the SADR agreed to the code of conduct for the referendum, to UN authority and to the principles governing the identification of voters. In 1998, the OAU summit debated whether the SADR could remain a member. By 1999, both parties accepted the revised UN peace plan. Of 150000 identified voter candidates, only a third have fulfilled the requirements of the identification commission. Morocco has filed thousands of complaints with the appeals process in an attempt to have the eligibility of rejected candidates reconsidered. These candidates for voter registration come from the three contested tribes with close links to Morocco. In 2000, the situation has deteriorated on the ground and the referendum process continues to be postponed. In January 2001, the Polisario announced an end to the ceasefire due to the passage of the Paris-Dakar Rally through Western Sahara without its consent. This was considered a serious provocation by the Moroccan authorities. The current mandate of the Minurso expires at the end of February 2001, and the political resolution of the dispute remains difficult to achieve.

\section{The Internal Dynamics of the Sahrawi Society and the Role of Women in Politics}

Many Sahrawis ${ }^{7}$ live in refugee camps, run on a semi-autonomous basis by Polisario in south western Algeria, or in the Moroccan-controlled territory. The refugee camps are situated in the Algerian desert, near the border between Algeria and the SADR. The camps are divided into four districts (wilaya) bearing the names of the Western Saharan cities; El Ayoun, the capital of the Western Sahara; Smara, the sacred town; Dakhla, the largest port and Aousserd, a 
little town in the interior. Each camp is sub-divided into six or seven villages (daira), and each village into four quarters.

The UN and various agencies keep refugees alive through a huge and costly relief effort. The Sahrawi have also created desert gardens, growing fruit and vegetables, and have set up a free education and healthcare system, with schools, colleges and hospitals. Furthermore, literacy has been raised from five to $95 \%$ in 25 years, and many young Sahrawi go on to study at universities in countries such as Spain, France, Algeria, Libya, and Cuba. The organisation of the camps is almost entirely in the hands of women. The majority of men do not live in the camps, as they are in the army.

Consequently, women play an important role in the Sahrawi society. ${ }^{8}$ The situation of war and exile has further pressed women into taking part in public life and in the political struggle for independence. It has been argued that national movements accelerate the mechanisms of the women's participation, as their support is needed to advance the national cause. However, in some cases, as in Algeria, once the 'revolution' is achieved, women may be forced back to more traditional roles, unless they actively impose their participation in public life. In the nomadic context, women have always played two major roles, guaranteeing the livelihoods of the family in the rigorous environmental conditions and ensuring the transmission of cultural heritage and social cohesion.

The role of women has been particularly important in the nomadic context, where men may be absent for long time from the camps. However, the sedentarisation since the 1960s transformed the traditional nomadic way of life. Since 1975, war and exile drastically changed the situation, and Sahrawi women have consciously applied some traditions of nomadic society in the new socio-political context. Today, the refugee camps are managed in a traditional way and women play a leading role in the survival of the Sahrawi culture. The role of culture as a means of strengthening the national identity and survival of the group is considered an important part of the struggle for independence. The women have accepted their motherhood as a political necessity as well as a social consequence of the need for demographic growth. This conservative function of women in the group is maybe more important than their institutional presence in political life and leading formal political institutions of the SADR.

At the political level, Sahrawi women have created national organisations, such as the National Union of Sahrawi Women (NUSW), ${ }^{9}$ begun in 1979 on the initiative of the Polisario Front. Today the NUSW has 10000 members in the refugee camps in Tindouf, the occupied and liberated areas of the Western Sahara and living abroad as emigrants, organised in local and regional offices. The NUSW has three objectives. Firstly, it aims to mobilise women and reinforce their role in the struggle for the liberation and independence of the Western Sahara. Secondly, it aims to improve women's level of education and training, through literacy campaigns, professional training, and political seminars. Finally, it seeks to make women aware of their social role after independence.

At the international level, the International Forum for Solidarity with the Sahrawi Women aims to enhance the participation of the Sahrawi women in public life. The participation of women in the reconstruction and management of the country depends on their capacities. There are specific schools created for women; and for children, there are day care projects, nursery schools and primary schools. In addition, the Sahrawi people rely on songs, story 
telling, drawings and paintings to transmit their traditions and history to the younger generations. $^{10}$

\section{Bilateral dispute Between Morocco and the Polisario}

Until the 1990s, Morocco did not consider the Polisario a legitimate voice and consequently, it refused to have any direct talks with it. Since the 1990s, the dispute mainly involves Morocco and the Polisario, although neighbouring countries and the international community continue to play an important role in the efforts to resolve the matter. The organisation of the referendum for self-determination is the key issue at stake.

\section{The Underlying Questions of the Western Saharan Dispute}

The structure of antagonism in the Western Saharan dispute is complex. First, there is a fundamental disagreement between Morocco and the Polisario on the status of the Sahara, supported by the UN resolutions and the ICJ decision. In particular, the dispute on voter eligibility for the referendum has undermined international efforts to resolve the conflict. Second, there is a dispute between Morocco and other North African countries, especially Algeria and Libya, on their support to the Polisario front, perceived as interference in Moroccan internal affairs. Consequently, over the decades, the Western Saharan question has threatened the regional stability of North Africa. Third, there is a great divergence between the OAU and Morocco on the principle of inviolability of existing state borders and on the admittance of the SADR as an OAU member state.

At first sight, the dispute seems to raise very fundamental national issues, opposing Moroccan historical sovereignty over the Western Saharan territory to the internationally recognised Sahrawi people's right to self-determination. However, the economic importance of the Western Saharan territory, with the world's richest fishing grounds, huge untapped phosphate deposits and significant oil reserves, is the main underlying factor in the Western Sahara conflict. ${ }^{11}$ The economically interesting area is situated in the 'triangle' linking Bou Craa, Smara and El Ayoun. ${ }^{12}$ The exploitation of fish resources ${ }^{13}$ and phosphates remains a crucial source of revenue for the Moroccan economy. ${ }^{14}$

\section{Historical Representations and Ideological Claims: the 'Sahrawi people' vs 'Greater Morocco'}

The Western Saharan dispute has an important rhetorical dimension, as both parties appeal to some fundamental national concepts to justify their claims over the Saharan territory. In particular, the recent formation of the 'Sahrawi nation' is an interesting geopolitical question. ${ }^{15}$ It challenges the Moroccan national identity, based on historical ties with the Sahara. I propose to briefly analyse the main components of the ideological discourse of the Sahrawi people and the Moroccan leaders.

Western Sahara, 1995

Damis, 1983

Beslay, p181

The European Commission is currently negotiating a new fisheries' agreement with Morocco, granting access for European fishing boats to the Moroccan maritime area. The negotiations include the maritime area belonging to the Western Sahara, thus the international agreement with the European Commission contributes to the establishment of Moroccan control over the region's rich fishing resources. De Saint Maurice, pp174-177.

Morocco is one of the world's largest exporters of phosphate (Europa Yearbook 1999)

Lacoste, pp80-84 
The emergence of the 'Sahrawi people' dates back to the 1960s. Before, nomadic tribes, mainly belonging to the Reguibat confederation, populated the territory without constituting any supra-tribal identity. The origin of the Sahrawi people is multiple: on the one hand, the Reguibat confederation of nomadic tribes had superficially recognised the authority of sultans, without, however, being subordinated to the sultans' authority. Similarly, the Spanish were mainly present in the coastal areas, having only superficial authority over the nomadic population until the 1960s, when the sedentarisation of the Sahrawis accelerated. On the other hand, in the 1940s, the Spanish authorities expelled several Moroccan nationalists, who were hiding from the French police in 'Spanish Sahara', to the Rio de Oro region. Finally, before Moroccan independence in 1956, many Moroccan extreme-left wing activists were operating against the French from Southern Morocco and Sahara, and turned against the conservative regime in Morocco after the independence. Since 1956, these activists also supported the Algerian nationalists. As a result, the French troops organised a military operation called 'Écouvillon' in 1958, backed by Morocco, in order to eliminate its political opponents in the Sahara. The surviving Saharan activists, of Reguibat and Moroccan origin, resented Morocco's cooperation with colonial powers. This resentment was transformed into a national movement for the Sahrawi people.

In the early 1970s, a small group of Sahrawi students, under the leadership of El-Ouali Mustapha Sayed, decided to fight for the end of Spanish rule in Western Sahara. The Sahrawis from southern Morocco, western Algeria, northern Mauritania and Western Sahara joined forces and formed the Polisario in $1973 .{ }^{16}$ The movement was inspired by anti-colonial, revolutionary thoughts. It was fighting for 'national liberation from all forms of colonialism and the achievement of complete independence'. ${ }^{17}$ The declaration of the SADR in 1976 fundamentally transformed the position of the Sahrawi activists. The recognition of the SADR as a legitimate 'state' by many African countries changed the nature of the legal battle between it and Morocco. It also increased the international legitimacy of the Polisario as the political representative of the Sahrawi people. ${ }^{18}$

According to the defenders of the Sahrawi cause, 'statehood' is justified by:

- the existence of a specific Saharan territory belonging to the Sahrawi, although currently forcefully 'occupied';

- a distinct population recognised as the Sahrawi and governed democratically;

- a specific language, 'Hassaniya', distinct from the dialects in the neighbouring populations;

- a modern structure of government; and

- sovereignty and autonomy of the SADR as a political entity.

The fundamental claim concerning a right to self-determination of the Sahrawi people is recognised by international law, the ICI's decision and numerous UN resolutions.

Morocco has claimed the Saharan territory since the country's independence in 1956. However, the Saharan question became crucial following the attempted coup d'états in 1971 and 1972, when King Hassan II sought to re-establish his legitimacy as a spiritual and political leader of the country. The question of the Western Sahara offered an extraordinary opportunity to restore historical legacy of the Alawite monarchy and Moroccan nationalism, to mobilise the population for the marocanity of the Western Sahara and to engage Moroccan 
army in the long war, thus diminishing the risk of military attempts to overthrow the government. King Hassan II $^{19}$ stressed the importance of the 'historical continuity' of the Moroccan kingdom, personally guaranteed by the monarch. The Moroccan claim to Western Sahara forms part of a larger claim to territories, called 'Greater Morocco', composed of tribes offering their allegiance to the Moroccan dynasties. ${ }^{20}$ The question of Sahara has become a highly delicate issue in Moroccan politics, since the marocanity of Sahara is the basis for Moroccan political consensus, and a founding pillar of the Moroccan identity, along with the monarchy and Islam.

The Saharan war has been a serious economic burden to Morocco. However, there is quasi-unanimous national consensus on the Saharan question ${ }^{21}$ and Moroccan media continues to be very critical of the UN efforts to organise a referendum. Even the political opposition defends the national cause. ${ }^{22}$ Also, the ancestors of most religious leaders, the marabouts, originated in Western Sahara, and their political influence has played a key role in the Moroccan determination to keep the territory as a part of the Moroccan 'fatherland'. Also, Moroccan prestige in the Arab world is at stake, and it could not simply lose the Saharan territory without that being undermined.

At the international level, Morocco ${ }^{23}$ has justified its claims to the Western Sahara on the basis of the legal principle of 'territorial integrity'. The Western Sahara constitutes the 'African roots of Morocco'. According to Moroccan views, it is unfair that only 'Moroccan Sahara' is contested, whereas Algeria and Libya have kept their Saharan territories without international protests. Also, according to these views, the Sahrawi do not form a people ${ }^{24}$ and most Sahrawi are waiting to 'join the Moroccan Fatherland'.

To conclude, the Saharan question articulates a historical process of Moroccan dynastic nation building and a concrete experience of the Saharan political activists, who transformed their resentment into a national mobilisation for the independence of the Sahrawi people.

\section{Diplomatic strategies and military mobilisation}

The military balance in Western Sahara is very unequal. On the one side, there are more than 100000 heavily armed Moroccan conscripts, deployed along the fortified wall, built in the 1980s and stretching for nearly 1500 kilometres, and surrounded by razor wire, minefields ${ }^{25}$ and forts. Opposing the Moroccans is a group of about 20000 light-armed guerrillas of the Polisario Front. ${ }^{26}$ Recently, frustration and disillusion are increasing among the Sahrawi population, and the Polisario has expressed its readiness to resume fighting if Morocco continues to break the ceasefire and to obstruct the referendum process. In the current situation, the eventual resumption of Sahrawi military efforts against Morocco would receive strong and arbitrating between other political actors. Waterbury, 1970 1960 , on the grounds that it was an artificial creation of French colonialism. Morocco finally recognised Mauritania in 1969.

21 Lacoste, p86

22 One of the famous opponents of the Moroccan regime, Abraham Serfaty, who defended the autonomy of the Sahara in exile for decades, has returned back to Morocco in 1999 following the accession of Mohammed VI to throne.

Ibid, p25

The use of anti-personnel mines constitutes a serious security threat. Morocco and the UN have signed a military agreement to identify and destroy mines and unexploded bombs still buried in the Western Sahara in 1999. 
support from the whole population, whereas in Morocco, the economic situation and the people's aspirations may not be favourable to a large-scale war effort in the Sahara. This could lead to an endless guerrilla war with no political issue. Therefore, military confrontation does not appear to be a suitable, nor preferable option in the Western Saharan question.

Morocco's strategy in the conflict has changed from its initial military deployment and occupation of the Western Saharan territory to the official acceptation of the UN peace plan and the idea of a referendum. Nevertheless, despite international pressure, Morocco has continuously obstructed the implementation of the UN peace plan in several indirect ways, including ceasefire violations, blocking of the UN peacekeeping forces and manipulation of voter identification and registration. ${ }^{27}$ Meanwhile, Morocco has initiated a large-scale settlement policy in the Western Saharan cities like El Ayoun, by offering tax relief, higher salaries and other incentives, in order to strengthen its presence in the region, officially considered as one of the Moroccan 'provinces'. Although the Western Saharan conflict has been a financial burden to Morocco, it has not undermined its firm commitment to the marocanity of Sahara.

The diplomatic efforts of both parties have been intense since the 1970s. In the 1990s, the Polisario has been effectively transformed from a guerrilla movement to a diplomatic lobbying organisation. ${ }^{28}$ It looks for international recognition of the self-determination of the Sahrawi people from relevant international bodies. Also, the Polisario has been successful in mobilising the solidarity of the international public opinion for the Sahrawi cause. Morocco, in contrast, has taken full advantage of its western alliances and its international prestige to put pressure, in particular on the African countries, to stop supporting the Polisario, and, as a consequence, some countries have withdrawn their recognition of the SADR. ${ }^{29}$ Furthermore, Morocco has concluded international treaties, such as the fisheries agreement with the European Commission, which reinforce its de facto control over the Western Saharan territory and its natural resources.

Popular mobilisation is based on the ideological discourse on national identity. The 'Green March' in 1975, based on historical legitimacy, mobilised a fervent popular support for the long and bloody war in the Sahara. Similarly, the Polisario fighters express their nationalism in their support for the SADR's independence, referring to 'the legitimate right to take up arms to defend the inalienable rights and national sovereignty in Western Sahara'. ${ }^{30}$

\section{Political Models and State Structures}

Both Morocco and the SADR aim to normalise their political life and administrative structures with regard to the Saharan territory. Despite apparent democratic changeovers in political life, it can be argued that power seems to remain in the hands of a limited circle of decision-makers, and in particular, the issue of Western Sahara, considered as a raison d' état, is excluded from public debates in civil society.

Since 1976, Moroccan authorities have made great efforts to create an impression of

Voter identification proved to be far more complex than expected, as members of the same tribal subgroups, who had to be identified individually with the assistance of their respective cheikhs, were dispersed in different locations and means of communication were limited. Similarly, the Moroccan authorities have obstructed the access of many Sahrawi to the UN. Also, Morocco has been accused of 'fabricating' the potentially eligible voters by subordinating cheikhs, whose task is to recognise members of Sahrawi tribes. De Saint Maurice, p103 
normality in the 'Moroccan Sahara'. ${ }^{31}$ In theory, the annexed territory was to be administrated in the same way as the rest of Morocco. Three new provinces were created, with capitals at El-Ayoun, Smara and Boujdour. They were sub-divided to 'circles' and at local level, to 'communes'. King Hassan II appointed the governors. Likewise, local, provincial and parliamentary elections were held in the Moroccan-controlled territories during 1976-77, and the Rabat authorities pointed to the election of pro-government candidates as evidence of popular support for integration to Morocco. Ever since, Morocco considers the Western Sahara as being its 'Saharan provinces'. The project of regionalisation, adopted in 1997, includes the Saharan territory. It was first divided into two provinces, El Ayoun and Dakhla, and in 1998, a third province, Aoussert, was created. ${ }^{32}$ The Saharan territory has thus de facto become an integral part of the Moroccan kingdom. Furthermore, Saharan affairs belong to the exclusive domain of the monarch and the Ministry of Interior ${ }^{33}$ and no public debate is allowed on the Sahara question.

The Moroccan political tradition uses popular referendums or consultations to justify royal decisions and to mobilise the people behind national projects. Following this logic, the eventual referendum in Western Sahara could only 'confirm' the claims. Morocco seems to be determined to obstruct the referendum process as long as its outcome remains uncertain. Since the change of the Constitution in 1996 and the elections in 1997, Morocco formally enjoys a greater political freedom, crystallised by the political changeover to the socialist government of Abderrahmane Youssoufi. The opening of political space with King Mohammed VI in 1999 has further activated civil society groups, claiming compensation for the families of the 'disappeared' political opponents, including many Sahrawi. ${ }^{34}$ However, these political changes have not affected the Moroccan stance vis-à-vis the Saharan question. ${ }^{35}$ Recently, Morocco has proposed a 'political solution' involving some 'federative' or 'confederative' arrangement for Western Sahara, but its modalities remain unclear.

The Constitution of the SADR, ${ }^{36}$ adopted for the first time in 1976, provides for a republican, semi-presidential system, in which the balance of powers is respected. The official language is Arabic and Islam is the state religion. The Sahrawi National Council is the legislative body, which controls the executive power. It may adopt motions of censure against members of the government, potentially leading to their resignation. The SADR has an independent judiciary. The head of state is the secretary-general of the Polisario, with a mandate to govern for three years. He nominates the prime minister, leads the country's general political orientation and is also the head of the armed forces. The government ensures the executive power, and is accountable to the head of state. The Constitutional Council ensures the constitutionality of laws and the legality of elections.

The holding of elections to the National Council, most recently in 1998, and the adoption of a motion of censure leading to the change of the government in 1999, aim to give the impression of normal political life in the SADR. However, the leadership of the Polisario has remained in the hands of a limited circle of decision-makers. There is confusion between the Polisario and the SADR ${ }^{37}$ The democratic façade is used to justify the legitimacy of the SADR as

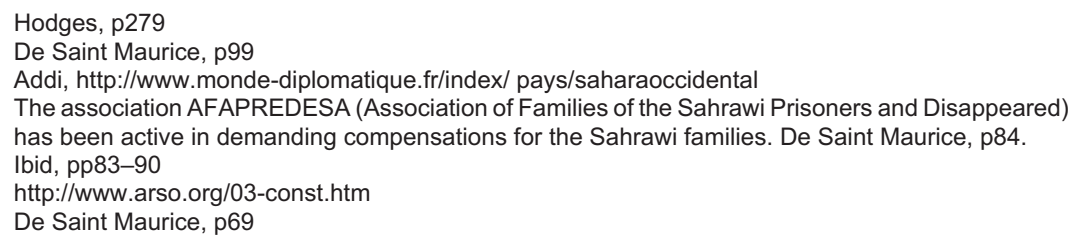


an established state, recognised by many countries. The Polisario remains the only internationally recognised representative of the Sahrawi people. There are other Sahrawi organisations, but most of them are pro-Moroccan and campaign for integration.

\section{Issue of the Referendum for Self-determination and Status of Peace Efforts in Western Sahara}

The nucleus of the Western Saharan dispute lies in the question of whether the people who inhabit the region will be consulted in a meaningful and internationally acceptable manner. ${ }^{38}$ The right to be consulted, known as the right to self-determination, is firmly embedded among the general principles of international law. In the decolonisation process, the preferred method for the UN to ascertain the wishes of an indigenous population has been by means of a referendum or plebiscite under its auspices.

The idea of a referendum for self-determination dates back to 1965, when the UN passed its first resolution on the Western Sahara. The resolution was directed toward Spain, which considered Sahara to be its 'overseas province', thus excluding any possibility of the people deciding on their status. Subsequent resolutions in 1967 and 1973 focused on the desirability of holding a referendum to ascertain the wishes of the population. The UN approach was also adopted by the OAU. The Spanish government began to accept the principle of a referendum in 1967, but it has been argued that Spanish support for a referendum could be seen as a tactic for perpetuating its presence in the territory ${ }^{39}$ Morocco has used same tactic in the $1990 \mathrm{~s}$.

In 1974 the Spanish authorities took a census of the Western Sahara, showing a total of 73497 Sahrawi living in the territory. However, the census did not take account the Sahrawi living outside the Saharan territory, estimated around 200000 in $1974 .{ }^{40}$ In 1975, the ruling of the ICJ denied both Moroccan and Mauritanian sovereignty over Western Sahara, by referring to the absence of an effective territorially based authority in Western Sahara. ${ }^{41}$ However, the Madrid Accords provided for the Spanish withdrawal and the partition of the land between Mauritania and Morocco. The Accords did not mention any referendum or representation of the Sahrawi.

The OAU has been closely involved in the Western Saharan dispute since the declaration of SADR. The first attempt to resolve the dispute in the OAU framework was the so-called Wise Men's Committee ${ }^{42}$ (Comité des Sages), mandated to investigate the question in 1978. Its recommendations marked the birth of the referendum idea within the OAU. Morocco rejected the idea, annexed new parts of the Saharan territory (Tiris el-Gharbia) and stated its intention to resettle Moroccan civilians to 'its Saharan provinces', in the areas it controlled. This act of defiance against the OAU increased the support of African states for the Polisario and the SADR.

In 1981, Morocco for the first time endorsed the idea of a 'controlled referendum', which would 'confirm' Moroccan sovereignty. However, Morocco refused to consider the Polisario's right to participate and claimed that the Saharan affair should be settled among Morocco, Algeria and Mauritania. Meanwhile, the SADR was formally admitted a full member of the organisation in 1982, although it only took its full seat in 1984. Morocco withdrew from the

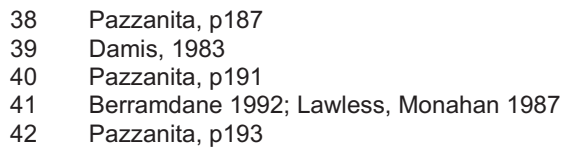


OAU. Despite all diplomatic efforts, the OAU failed to resolve the dispute, mainly due to its open support for the Sahrawi cause. ${ }^{43}$

Since 1985, the role of the UN in the settlement of the dispute was revitalised. It built upon the OAU referendum plans, and called for direct negotiations, a ceasefire and an interim administration in Western Sahara. During 1985-86 the UN secretary-general, Javier Pérez de Cuéllar, attempted to reconcile the parties by means of 'proximity talks', where the parties were spared the necessity of meeting face-to-face. The UN peace plan was agreed in 1990 and a ceasefire entered into force in 1991, paving the way for the beginning of the referendum process. Minurso was set up in 1991 to supervise an uneasy ceasefire between Moroccan forces and the Polisario and to hold a referendum allowing the Sahrawi to vote either for integration with Morocco or for the self-determination of Western Sahara.

The criteria for the eligibility of voters have been a major source of contention. ${ }^{44}$ Both Morocco and the Polisario estimated it was insufficient to rely primarily on the 1974 census. Identification of voters raised issues related to the criteria used, and the scrutiny applied, in determining the potential eligibility of thousands of Sahrawi. In fact, the issue of a voter list has a decisive impact on the outcome of the referendum.

The five discussed criteria are:

- a person has been registered in the 1974 census;

- a person lived in the territory as a member of a Sahrawi tribe in 1974 without being registered;

- a person is a descendant of persons belonging to either of the two first groups;

- a person's father was born in the territory; or

- a person is a member of a Sahrawi tribe and has lived in the territory for six consecutive years, or all in all twelve years, since 1974.

This extension of criteria by the Secretary-General Pérez de Cuéllar beyond the 1974 census has been considered a gesture of good will to Morocco. ${ }^{45}$ The Polisario has opposed in particular to the fifth criterion, which allows Morocco to register thousands of pro-Moroccan candidates on the voter list.

The choice offered to Sahrawi voters in the referendum is between independence and integration with Morocco. A third option is discussed, namely 'affiliation' to Morocco, under an undefined 'federative' or 'confederative' arrangement. The Polisario has reiterated its exclusive commitment to independence ${ }^{46}$ From its point of view, any proposal for Western Saharan autonomy within Morocco would be no different to complete integration with Morocco.

The Minurso's Identification Commission was established in 1993. In 1994, it began the process of voter identification. Procedural and operational irregularities slowed the process, and efforts to resolve differences between the parties were not successful. In May 1996, UN secretary-general Boutros Boutros-Ghali suspended the identification process and most Minurso civilian staff were withdrawn. The military component remained to monitor and verify the ceasefire. It has been argued that until 1997, the UN failed to remain impartial and ensure progress in the referendum process. ${ }^{47}$ 
In 1997, UN secretary-general Kofi Annan intensified the examination of the main contentious issues in a series of direct talks between Morocco and the Polisario, held under the auspices of his personal envoy, James Baker. These talks resulted in the 'Houston Accords'. In December 1997, Annan restarted the identification process. Despite a number of difficulties, identification of all applicants, other than those from three contested tribes, was completed in 1998. The three contested tribes, called tribes H41, H61 and J51/52, are composed of persons living in southern Morocco. They comprise 65000 persons and could make a difference in the outcome of the referendum if accepted as voters. ${ }^{48}$

In an effort to move the process forward, in 1998 Annan presented a package of measures, including a protocol on identification of the remaining applicants and a protocol on the appeals process. The Polisario accepted the package in 1998, and Morocco in March 1999.

Both sides agreed in April 1999 to expedite appeals once identification was completed. The provisional list of registered voters was published. It included 84251 names found eligible to vote out of 147249 identified. The agreement provided that appeals would be entertained only where new evidence could be introduced to establish a right to vote. However, during the appeals period, Morocco filed appeals for 79000 voters, virtually an appeal for every rejected candidate. ${ }^{49}$ It has been argued that the appeals process in fact starts the identification all over again.

Identification of applicants from the three tribal groupings was completed at the end of December 1999. Of 51220 individuals who presented themselves, 2130 were found eligible to vote. Although the identification process has been completed, the parties continue to hold divergent views regarding the appeals process, the repatriation of refugees and other crucial aspects of the UN peace plan.

Despite Annan's confidence that the peace plan and referendum can successfully bring an end to the conflict, numerous problems remain. An appeal process for rejected voters further complicates the work of the Identification Commission. Morocco refuses to hand over the full administration of the territory to the Minurso and retains its extensive civil security forces within the territory. Similarly, the United Nations High Commissioner for Refugees (UNHCR) was mandated to carry out a repatriation programme for eligible Western Saharan voters living outside the territory, but Morocco has obstructed its work on the ground. Morocco also refuses to publicly consider the possibility of an independent Western Sahara. In this context, it remains to be seen how the UN intends to ensure that the result of the referendum would be respected. In fact, despite both parties' official attachment to the referendum process, recent UN reports seem to more seriously consider the eventuality of a 'political settlement', although its modalities are not defined. ${ }^{50}$

The mandate of the Minurso was extended until 28 February 2001 by UN Security Council resolution 1324 (2000) of 30 October 2000. The council stressed that it extended the mandate of the mission with the expectation that the two sides 'will continue to try and resolve the multiple problems relating to the implementation of the Settlement Plan and try to agree upon a mutually acceptable political solution to their dispute.' The extension was recommended in October 2000 by the secretary-general in his report on the situation in Western Sahara. According to that report, there had been no progress in overcoming obstacles to the implementation of the settlement plan. 
It is not certain that the mandate will be further extended beyond February 2001, considering the lack of progress in the referendum process. Furthermore, the Polisario has threatened to resume fighting following the passage of Paris-Dakar rally through the Western Saharan territory in January 2001.

\section{International Dimension of the Western Saharan Question}

The international dimension of the Western Saharan dispute articulates on two levels. The first is the regional level, that is the relationships between Mauritania, Morocco, Algeria and Libya. The second is the global level, in particular the regional interests of the US, Spain and France. In the new global political context of the 1990s, characterised by the end of the cold war alliances, economic globalisation, and the threat of Islamic fundamentalism, most international actors have changed their strategies with regard to the Western Saharan question. ${ }^{51}$ Western Sahara was a strategic region during the cold war and its mineral resources were exploited. Despite the diminishment of its strategic importance after the cold war, the resolution of the Western Saharan question continues to have a fundamental impact on the stability of West Africa.

In the African context, the OAU commitment to decolonisation and the inviolability of existing borders resulted in the recognition of the SADR and the withdrawal of Morocco from the organisation. Most OAU countries have some unresolved border disputes, and they feared that the Western Saharan conflict might set a dangerous precedent. ${ }^{52}$ Also, the Western Saharan question need to be situated in the larger context of the Arab world, in which a dichotomy between moderate, such as Saudi Arabia, and radical, such as Libya, regimes has constituted the dividing line in the reactions to the conflict. The Arab League and the Organisation of Islamic Conference have supported Moroccan reconciliation efforts with Israel in the Middle East. The project of the Union of Arabic Maghreb (UMA), initiated in 1989 with the aim of promoting economic integration in North Africa, has suffered from the Western Saharan dispute, thus undermining the economic dynamics of the region. At the global level, the UN role in the preparation of the referendum process has been crucial and continues to be a determining factor in the efforts to find a solution to the last piece of unfinished decolonisation in Africa.

Algeria has never claimed the Saharan territory, but it has actively supported the Polisario's fight for the independence of Western Sahara. The revolutionary and anti-colonial stance of the Algerian state in the 1970s, the remnants of border disputes between it and Morocco, the possibilities for joint exploitation of mineral resources and for access to the Atlantic Ocean with the independent Saharan state, and finally, the willingness to reinforce a hegemonic regional position, have all contributed to its active involvement. In 1988, relations between Algeria and Morocco were improved, and both countries pledged to facilitate the self-determination process, thus implicitly recognising the Polisario as the legitimate voice. In the 1990s, the relations between Morocco and Algeria deteriorated, and Algeria reiterated its support for the SADR and the UN peace plan. However, Islamic fundamentalists, who play an important role in internal politics, do not agree with Algerian support for the Polisario. Algerian president Abdelaziz Bouteflika and King Mohamed VI have recently expressed their commitment to improve their relations and to seek solution to the Western Saharan question.

The involvement of Mauritania in the Western Saharan dispute stemmed initially from the country's fragility in relation to neighbouring Morocco and Algeria. Its aim was to safeguard a 
balance between different regional interests. Since signing a peace agreement with the SADR in 1979, Mauritania has taken a neutral stance in the dispute, although it continues to stress its close cultural ties with the Sahrawi. Also, Mauritanian economic interests in the region are at stake. It has been suggested that Mauritania could play an important role in the mediation of the dispute. ${ }^{53}$

Libyan financial and military support to the Polisario was based on its opposition to Morocco and its ideological and political affiliation with various radical movements all over west Africa. However, Libya did not recognise the SADR until 1980. This was due to Kaddafi's belief in Arab unity which would be further threatened by the emergence of a new, separate, state. ${ }^{54}$ Since then, relations between Morocco and Libya have improved and the latter's role in the dispute has dinimished.

Following its withdrawal from Western Sahara in 1975, Spain has attempted to officially maintain a neutral position vis-à-vis the dispute, although public opinion in Spain is openly in solidarity with the Sahrawi people. Also, cultural and linguistic ties remain strong and a number of Sahrawi activists live on the Canary Islands.

France has supported Morocco for its military importance and its commitment to the francophone movement. The relationship between Morocco and France has evolved over the years. Socialist President François Mitterrand, in office until 1995, was closer to Algeria than to Morocco, whereas conservative President Jacques Chirac renewed the alliance with the Moroccan moderate regime in 1995, in order to fight effectively against Islamic fundamentalism. France has remained silent on the Western Saharan question, officially stating a position of neutrality, although its solidarity with Morocco is well known. French civil society has recently mobilised an increasing solidarity with the Sahrawi people. France has so far refused to play the role of mediator in the dispute despite several requests..$^{55}$

Like France, the US has been a generous arms supplier to Morocco, which was an important ally during the cold war. Moderate and pro-western Morocco offers a strategic position commanding the southern access to the Mediterranean. The US has also been concerned about Libyan support to the radical Polisario, which is hostile to American interests. Currently, Morocco, known for its conservative Islamism, plays a crucial role in the fight against the Islamic fundamentalism, endangering the regional geopolitical stability and French and US interests in north Africa. The US also sees the resolution of the Western Saharan question in the broader context of its 'new African policy', launched by President Bill Clinton in 1998. This new policy aims to ensure market access to Africa by US companies. Following this logic, conflict and instability undermines the economic dynamics and therefore, conflict resolution is the key element of the new US foreign policy ${ }^{56}$ The appointment of James Baker as the UN special envoy to Western Sahara reflects this active involvement in international mediation. In recent years, the US Congress has taken an active stance in support of the referendum process.

Moroccan relations with the European Union (EU) have also affected its stance on the Western Saharan question. Morocco is an important player in the Euro-Mediterranean economic cooperation ('the Barcelona process'), aiming to create a Mediterranean free trade zone by 2010. The position of the European institutions vis-à-vis the Western Saharan question is not coherent. On the one hand, the European Parliament has urged the conflicting parties 
to find a solution to the dispute and to agree on the issues related to the referendum. On the other hand, the European Commission, as a part of its 'economic cooperation', is currently negotiating a fisheries agreement with Morocco. The agreement includes the maritime territory of Western Sahara, contributing to de facto international recognition of Moroccan sovereignty in the Saharan territory. ${ }^{57}$

\section{Impact of Religion on the Western Saharan Question}

Muslim political culture ${ }^{58}$ is based on the unity between the religious and political spheres. Therefore, the only division that can be traced is between the 'ideal politics' (unity of the Muslim community, called umma, and Islam) and the 'necessary politics' (deficient human government constituted against tribal dissidence). The idea of a nation, presented in the 19th century, threatens to fragment the religious umma into separate nation-states, which is in contradiction with the Muslim ideal unity. This leads to the ambiguity between the reference to a particular nation (such as Egypt) and the reference to the transnational and extraterritorial 'Arabic, and Islamic, Nation'. This ambiguity of the Muslim idea of national space, universal and particular, illustrates the fundamental fragility of the nation-state in the Muslim world, where political power often justifies itself through symbolic rhetoric based on Arabness, Islam and the glorious past. Both Arabic nationalism and Islamic fundamentalism base their arguments on the basic contradiction between the unity of Arabic or Islamic community and the fragmentation of this community into nation-states. Both use the ambiguous mixture of religion and Arabic identity as a political instrument, although Arab nationalism recognises open links with socialism and secular revolutionary ideas.

Following the logic of Muslim politics, Islamic fundamentalists oppose the idea of the Sahrawi state. They perceive that a new state would further fragment the Islamic community (umma islamiya). Furthermore, the Polisario is considered as being 'a secular revolutionary movement', despite official Islamic references in the SADR constitution. ${ }^{59}$ Also, Morocco has received western support due to its perceived moderate stance vis-à-vis Islam and its open opposition to radical Islamism. The impact of religion in Western Saharan question has thus played an important role in the positioning of third parties with regard to the eventual independence of the Sahrawi.

\section{Concluding Remarks}

The unfinished referendum process in Western Saharan continues to undermine the regional stability and economic growth in North Africa. With the exceptions of the UN efforts, the international community has remained relatively passive in the resolution of the dispute. This passivity has resulted in the continuous postponement of the referendum process and in the de facto integration of the Western Saharan territory to Morocco, despite the provisions of international law and several UN resolutions. Current situation on the ground is tense, and the lack of political settlement between Morocco and the Polisario continues to undermine the application of the UN peace plan. The current stalemate in Western Sahara is in contrast with the successful UN action in the referendum process in East Timor, resolving another unfinished piece of decolonisation in 1999. Despite serious difficulties, the successful example of East Timor gives new hope for a peaceful resolution of Africa's longest lasting conflict. 


\section{Bibliography}

Addi L, 'Transitions maghrébines sous le regard des armées-Introuvable réconciliation entre Alger et Rabat', Le Monde Diplomatique, December 1999, http://www.monde-diplomatique.fr/index/pays/ saharaoccidental.

Amoretti B S, 'Women in the Western Sahara' in Richard Lawless, Laila Monahan (eds.), War and Refugees - The Western Sahara Conflict, London, Pinter Publishers, 1987, pp186-191.

Badie B, Les deux Etats- pouvoir et société en Occident et en terre d'islam, Paris, Fayard, 1986.

Barbier M, Le conflit du Sahara Occidental, Paris, L'Harmattan, 1982.

Berramdane A, Le Sahara occidental-enjeu maghrébin, Paris, Karthala, 1992.

Beslay F, Les Réguibats-de la paix française au Front Polisario, Paris, L'Harmattan, 1984.

Damis J, Conflict in Northwest Africa - The Western Sahara Dispute, California, Hoover Institution Press, Stanford University, 1983.

De Froberville M, Sahara Occidental-la confiance perdue, l'impartialité de l'ONU à l'épreuve, Paris, L'Harmattan, 1996.

De Saint Maurice T, Le Sahara Occidental 1991 1999, l'enjeu de référendum d'autodétermination, Paris, L'Harmattan, 2000.

Hodges T, Western Sahara-The Roots of a Desert War, Connecticut, Westport, Lawrence Hill \& Company, 1983.

Lacoste Y, Questions de géopolitique-l'islam, la mer, l'Afrique, Paris, la Découverte, 1988, pp77-90.

Lawless R, Monahan L (eds), War and Refugees - The Western Sahara Conflict, London, Pinter Publishers, 1987.

Les fondements juridiques et institutionnels de la République Arabe Sahraoui Démocratique, Actes de colloque international de juristes tenu à l'Assemblée Nationale, Paris, le 20 et 21 Octobre 1984, Paris: L'Harmattan 1984.

Nugent P, Asiwaju A I (eds), African Boundaries-Barriers, Conduits and Opportunities, London, Pinter Publications, 1996.

Pazzanita A G, 'The Proposed Referendum in the Western Sahara: Background, Developments, and Prospects' in Zoubir Z H, Volman D (eds), International Dimensions of the Western Sahara Conflict, London, Praeger, 1993, pp187-218.

Ruddy F, 'The United States Mission for the referendum in Western Sahara: Lofty Ideals and Gutter realities', Former US ambassador statement, 16 February 2000, http://www.arso.org/Ruddy2000.htm

Tredano A B, Le Sahara marocain-une décolonisation pas comme les autres, Rabat, Confluences, 1991.

Waterbury J, The Commander of the Faithful, New York, Columbia University Press, 1970.

Western Sahara, OXFAM Belgium, Comité belge de soutien au peuple sahraoui, Brussels, 1995.

Zoubir Y H, Volman D (eds), International Dimensions of the Western Sahara Conflict, London, Praeger, 1993.

Inter-Press Service (IPS)

Western Sahara News, http://www.africanews.org/north/westernsahara/

Western Sahara Weekly News, http://www.arso.org/ 